\title{
THE EFFECTS OF PSYCHIC DISTANCE AND INTER-PARTNER FIT ON THE PERFORMANCE OF INTERNATIONAL JOINT VENTURES
}

\author{
Ishita Batra* and Sanjay Dhir \\ Department of Management Studies, Indian Institute of Technology (IIT), \\ Hauz Khas, New Delhi-110016, India \\ *Corresponding author: ishita.iitdelhi@gmail.com
}

Published online: 27 June 2019

To cite this article: Batra, I. and Dhir, S. (2019). The effects of psychic distance and inter-partner fit on the performance of international joint ventures. Asian Academy of Management Journal, 24(1), 151-173. https://doi.org/10.21315/aamj2019.24.1.7

To link to this article: https://doi.org/10.21315/aamj2019.24.1.7

\begin{abstract}
The impact of psychic distance stimuli and inter-partner fit on the performance of international joint ventures (IJVS) has not been adequately explored in the case of emerging economies. Another lacuna in literature is the analysis of the performance of IJVs in regard to the new normal business landscape. This study analyses the impact of psychic distances stimuli and inter-partner fit on the performance of IJVs in the context of new normal business landscape. The secondary data of 122 IJVs headquartered in India with $G 7$ nations is empirically tested. The study indicates that out of all psychic distances, administrative and economic distances significantly affect the performance of IJVS.
\end{abstract}

Keywords: psychic distance stimuli, inter-partner fit, international joint ventures, new normal, performance

\section{INTRODUCTION}

The business landscape has fundamentally changed over the last decade, especially resulting from the 2008 global financial crisis (Davis, 2009; Hamid, Everett, \& O’Kane, 2018; Ömür, Tunç, \& Düren, 2012). The post-crisis period is delineated by the slow growth rate of developed economies, low productivity, the large number of unemployed people, rapid technological advancement, uncertainties,

(C) Asian Academy of Management and Penerbit Universiti Sains Malaysia, 2019. This work is licensed under the terms of the Creative Commons Attribution (CC BY) (http://creativecommons. org/licenses/by/4.0/). 
and shorter product lifecycle. Research has viewed this cyclical trend as the "new normal" (El-Erian, 2010; Hitt, Li, \& Xu, 2016). These changes affect all the actors in an economy including companies and business landscape (Ömür et al., 2012). Presumably, companies should proactively change their strategies and mental make-up in order to succeed in the new normal business landscape (Ömür et al., 2012). Therefore, companies should strive to make strategic alliances, thereby sharing their competencies to succeed in the new normal world (Davis, 2009; Li \& Wang, 2019). Different forms of alliances can be formed; however, research has empirically found that the most extensively used alliance by organisations over the past decade is the international joint ventures (IJVs) (Barmeyer \& Davoine, 2019). In the new, the normal business landscape, organisations seeking to achieve high growth rate will prefer emerging economies for making IJVs (Ahsan \& Fernhaber, 2019).

According to various studies, IJVs gains competitive advantage by letting companies leverage on their partner's technology, capabilities, technical skills, resources, and also sharing risks (Barney, 1991; Culpan, 2008; Hamel et al., 1989; Lu \& Beamish, 2001). Although IJVs has been shown to have innumerable advantages, its instability rate is extremely high (Lowen \& Pope, 2008). Therefore, this study tries to understand the factors affecting the performance of IJVs. A plethora of studies have been done on the performance of IJVs especially in the developed economies (Alcantara \& Hoshino, 2012; Geringer \& Herbert, 1991; Glaister \& Buckley, 1998; Ren, Gray, \& Kim, 2009; Zhao, Ma, \& Yang, 2017), but little research has been done on the subject in regard to the emerging economies.

According to past literature, various perspectives of performance in regard to IJVs have been studied. Such perspectives are commitment according to Glaister and Buckley (1998) and Nakos and Brouthers (2008), bargaining power (Awadzi, 1987), conflict (Demirbag \& Mirza, 2000; Li \& Hambrick, 2005), justice (Luo, 2005), cultural distance (Gomez-Mejia \& Palich, 1997; Hutzschenreuter, Kleindienst, \& Lange, 2014; Kogut \& Singh, 1988; Yan \& Duan, 2003), and trust (Nakos \& Brouthers, 2008). However, the impact psychic distance stimuli have on the performance of IJVs has not been thoroughly explored. Since the origin of international business, distance has become an inevitable barrier in the collection, analysis, and interpretation of data in regard to the foreign market (Håkanson \& Ambos, 2010). Literature has connoted that with the advancement of technology, these frictions imposed by distance have now reduced or even disappeared (Cairncross, 1997; Head, Li, \& Minondo, 2018). Recent researchers, however, have articulated that distance still exists in the domain of international business (Kostova \& Marano, 2019; Fatehi \& Choi, 2019). The world is "semi-globalised" and therefore, distance, which is viewed in terms of culture, geographic, and 
administrative, economic distances still matter (Ghemawat, 2001). In light of this, this study aims at providing a comprehensive empirical analysis in regard to the impact that psychic distance stimuli have on the performance of IJVs within the context of the new normal business landscape. Besides, previous researchers have explored the connection that exists between inter-partner fit and IJVs' performance (Ren et al., 2009; Yan \& Duan, 2003). Inter-partner fit has been studied to determine the level to which partners realise projected synergies critical to a transaction's success. Different perspectives of inter-partner fit have been articulated in literature such as interfirm diversity (Parkhe, 1991), strategic asymmetry (Harrigan, 1988), strategic fit (Jemison \& Sitkin, 1986), and partners characteristics (Geringer \& Herbert, 1989). Prior work either failed to provide conceptual clarity or produced inconsistent findings of inter-partner fit as a construct, making it difficult to reconcile it (Yan \& Duan, 2003).

Accordingly, this study aims to fill the gaps that exist in the past literature through an examination of the impact of inter-partner fit and psychic distance stimuli on IJVs' performance in terms of size asymmetry, resource complementarity, goalcongruency, and competitive overlap in the context of new normal landscape. The researcher in this study reviewed past literature in relation to the new normal business landscape and factors impacting the performance of IJVs. We subsequently gathered a sample of 122 IJVs headquartered in India with G7 economies from 2009-2017 with the aim of finding out the impact of psychic distance stimuli and inter-partner fit on the performance of IJVs. Further, the study highlights the implications and limitations of the study, as well as, points out to the areas of future research.

\section{THEORETICAL DEVELOPMENT AND HYPOTHESES}

To determine the effect of psychic distance stimuli and inter-partner fit in regard to the performance of IJVs in the context of the new normal global business landscape, the literature in this study has been reviewed from two perspectives: new normal business landscape and factors impacting the performance of IJVs.

\section{New Normal}

The current business landscape is fundamentally different from the 2008 global financial crisis. Literature advocates that the global financial crisis has its own repercussions (Lane \& Milesi-Ferretti, 2018; Melville \& Reese, 2009; Ömür et al., 2012). Currently, the world is staring at the restructuring of the business cycle and the economic order. In the midst of these changes, some businesses are trying to 
survive and others are peering through the cloud of uncertainty on how to position themselves in this new world, which is all about the low growth of developed economies, falling productivity, high unemployment, and falling trade (Beck, 2018). These challenges are not temporary, but they are ongoing challenges, which require structural changes in doing business (Falkenberg \& Ashurst, 2010; Nachum \& Zaheer, 2005).

The business environment is changing due to the emergence of this new business landscape. The "New Normal" - something, which was earlier uncommon has begun to become more common (El-Erian, 2010; Hitt et al., 2016). The expression "new normal" was first postulated by Mohamed El-Erian of Pacific Investment Management Company (PIMCO) in 2009 to recognise the changes in the postcrisis period. Literature advocates that the economic readjustment will be more complex and uncertain as compared to financial readjustment (El-Erian, 2010).

One of the main elements of the new normal is the change in the approach to managing the situation. Organisations have to focus on what has changed and what has not changed for their industry, and in response, develop the competencies required to succeed (Ömür et al., 2012). Another focal characteristic of the new normal is the increased role of the government. The main agenda is to force companies to indulge in corporate governance, which means a surge of corporate transparency and an increase in government investment (Melville \& Reese, 2009).

In such a complex scenario, companies are compelled to focus on sustainable and long-term growth. They have to update their strategies and mental make-up to succeed. "To remain competitive, companies must learn to harness their strengths, focus on key competencies and stick to their core business" (Melville \& Reese, 2009). Thus, organisations must understand how the new normal conditions unfolding in different domains and different locations may have a diverse impact on their performance and survival (Tan \& Mohd Nasurdin, 2010).

\section{Performance of IJVs}

Research has shown that the performance of IJVs is the most critical concern about IJVs in regard to the new normal business landscape. As such, the performance of IJVs is viewed as a critical concern mainly due to two main reasons: the imposed cost of failure and the social cost of failure. The economic environments on which these IJVs operate have to bear these costs (Lee \& Beamish, 1995). The measurement for IJVs performance is a debatable area (Das \& Teng, 2003; Geringer \& Herbert, 1991; Hutzschenreuter et al., 2014; Osland \& Cavusgil, 1996; Zhao et al., 2017). One major measurement aspect that can be utilised to measure 
the performance of IJVs is the use of an appropriate indicator. Various scholars have used different yardsticks like financial indicators to evaluate the performance of IJVs such as profits, growth, or sales (Lu \& Beamish, 2001, 2004) while others include survival as shown by Geringer and Herbert (1991) and Killing (1983), and its duration stated by Harrigan (1988) and Kogut (1988).

In this study, financial indicator-return on assets (ROA) is utilised in the measurement of the performance of IJVs. The financial measure is both used independently as the yardstick, as well as, used to validate subjective measure (Nasurdin, Jantan, \& Fadzil, 2004; Dhir, Ongsakul, \& Batra, 2018). There is also a high correlation between the performance of IJVs and ROA and return on sales (ROS) (Choi \& Beamish, 2004).

\section{Determinants of Performance of IJVs}

\section{Psychic distance stimuli}

Psychic distance stimuli as a concept were introduced by Beckerman (1956) and this concept has since gained popularity after it was explored at the University of Uppsala (Geringer \& Herbert, 1991). Over time, psychic distance has emerged as the most researched concept in regard to international business. It has been studied from different perspectives entry mode strategies, subsidiary performance, and capability transfer. Psychic distance has been defined by several scholars. We adopted the definition given by Sousa and Bradley (2006, p. 51) where psychic distance is "the individual perception of the differences between the country of origin and the foreign country". This definition includes the impression of perception and distance and both manifest the nature of this concept (Sousa \& Bradley, 2006). According to various studies, psychic distance stimuli are used as a synonym of culture distance; however, many scholars including Pankaj Ghemawat (2010) have posited that it is not simply cultural distance, but incorporates other perceptions too. This redefinition process of psychic distance continued and has led to a better understanding of the concept.

Today's world is "semi-globalized" and therefore, borders continue to matter (Ghemawat, 2010). Thus, apart from the cultural distance, distance comprises of other dimensions, which are geographic distance, administrative distance, and economic distance. These four dimensions form the CAGE (cultural, administrative, geographic, and economic) framework, help to identify the differences between countries and provide the basis for such differences (Ghemawat, 2010). However, very little work has been done in the past to analyse the effects of these four dimensions of distance (Karunaratna \& Dow, 2006). 


\section{Cultural distance}

Culture is an extremely complex concept. This concept has gained popularity owing to Hofstede's (1980) work, and it is currently expansively used in international business research. According to Hofstede (1980), culture could be viewed as "the collective programming of the mind which distinguishes the members of one human group from another".

As noted by Weber, Shenkar, and Raveh (1996), corporate and national culture, though related, are different constructs. The most common method used to measure national cultural distance is the Hofstede national cultural distance (Hofstede, 1980), which bases its computation of culture scores on the six Hofstede dimensions: individualism, power distance, uncertainty avoidance, masculinity, long-term orientation, and indulgence vs. restraint (which was added later). Extant literature suggests that cultural fit affects the performance of alliances by allowing multiculturalism and preventing too much control. Therefore, such firms perform better compared to less permissive firms (Chatterjee, Lubatkin, Schweiger, \& Weber, 1992; Dhir, 2017; Li, 2003).

Cultural distance enhances the difficulties that the companies face in identifying and interpreting the signals (Damanpour, Devece, Chen, \& Pothukuchi, 2012; Evans, Treadgold, \& Mavondo, 2000; Håkanson \& Ambos, 2010; Hamilton, Dana, \& Benfell, 2008). Therefore, a cost is incurred because of misperceiving or misinterpreting signals like customers preferences, which can likely affect the performance of the company. Hereby, it is hypothesised that:

H1: Cultural distance and IJVs performance are negatively related in the new normal business landscape.

\section{Administrative distance}

Administrative distance is extracted from the institutional theory. This theory is of paramount interest to IJVs as an institutional environment of a firm is considered to be the focal factor, which determines the firm structure and firm behaviour (Scott, 1995). The regulatory distance consists of legal, regulations and government policies (Scott, 1995). Upcoming economies are marked by informalities and immature government policies and regulations, indicating transparency, intellectual property rights, corporate governance, and market regulations may not be reliable and mature as compared to developed economies (Lasserre, 1999; Lin, Chen, \& Lin, 2014; Marquis \& Raynard, 2015; Marquis \& Zhang, 2011). Moreover, research shows that governments in developing economies are susceptible to internal 
issues and external tensions, a fact that makes it a risk for a business to operate in these economies (Hiatt \& Wesley, 2014). Prior literature also connotes that these factors bear more impact in regard to the performance of IJVs in emerging markets compared to more mature markets (Meyer, Mudambi, \& Narula, 2011). This is because institutional immaturity has been seen to raise the transaction cost and risk level in emerging economies (Child, Chung, \& Davies, 2003; Meyer et al., 2011). Immature or an unstable governance system leads to an increased level of uncertainty and risks for working in the respective country (Kaufmann, Kraay, \& Mastruzzi, 2009). As pointed out by Nakos and Brouthers (2008), different institutional contexts in different national environments will affect the ability of the company to exploit and divergently enhance its capabilities. Hence, it is hypothesised that:

$\mathrm{H} 2$ : Administrative distance and IJVs performance are negatively related in the new normal business landscape.

\section{Geographic distance}

This type of distance can be viewed as being separated physically by borders between countries. Geographic distance is an index of trade resistance due to its affiliation with the cost of transportation and communication (Beckerman, 1956). As pointed by out Srivastava and Green (1986), the geographical distance can negatively affect the intensity of trade between different countries. However, technological advancements help in reducing trade resistances like the cost of transportation and communication, but the physical distance remains a critical obstacle in trade globally (Håkanson \& Ambos, 2010; Hutzschenreuter et al., 2014). Extant literature has found the linkage between distance and shipping costs and trade (Clark, Dollar, \& Micco, 2004). Regarding this, geographic distance leads to an increase in the complexities, which make it difficult for a firm to successfully coordinate the operations of organisational units. Therefore, it is hypothesised that:

H3: Geographical distance and IJVs performance are negatively related in the new normal business landscape.

\section{Economic distance}

This is an important concept in international business as it acknowledges the purchasing power, gross domestic product (GDP) or transportation and communication infrastructure disparities (Hutzschenreuter et al., 2014). As such, these are critical disparities between developing and developed economies. For instance, developing economies have been seen to have a higher proportion of 
manufacturing, labour-intensive, as well as large-scale heavy industry sectors (Marquis \& Raynard, 2015; Murrell \& Wang, 1993; Wang, 2006). However, research shows that the developed economies have a moderately low GDP growth rate and are marked by a high GDP per capita. This posits that such economies have reached industrial development maturity state. These differences lead to increased risks and uncertainties, which in turn amplify the costs incurred in operating a business in other economies. The prior literature has shown that business models can be adjusted to the countries with low economic distance. Therefore, the higher the economic distance, the more negatively it will impact the performance of businesses. In light of this, it is hypothesised that:

H4: Economic distance and IJVs performance are negatively related in the new normal business landscape.

\section{Inter-partner fit}

Extant literature has pointed out the relationship between inter-partner fit and IJVs performance. Inter-partner fit determines to what extent merged organisation realises anticipated synergies critical to transactional success. There are different notions of inter-partner fit, which have been explored - strategic symmetry, competitive overlap, and resource complementarity among others (Beamish, 1988; Hill \& Hellriegel, 1994; Inkpen, 2000).

\section{Size asymmetry}

Size asymmetry is a relatively important notion of inter-partner-fit. Research shows that there is a negative connection between size asymmetry of parent firms and the performance of IJVs (Atolia, Gibson, \& Marquis, 2018; Osland \& Cavusgil, 1996; Sim \& Ali, 2000). Transaction cost theory explains the linkage between the size of the parent company and performance. Prior research has noted that asymmetry in size of the partners' firm will negatively impact stability as there will be a mismatch in the strategic mission, culture, and bureaucracy. This will ultimately affect the performance of IJV (Dhir \& Mital, 2013; Li \& Hambrick, 2005).

H5: Size asymmetry of parent firms and IJVs performance are negatively related in the new normal business landscape. 


\section{Competitive overlap}

Competitive overlap is another important perspective of inter-partner-fit. Previous research has shown the connection between competitive overlap and the performance of IJVs. As such, the IJVs between competitors would likely make parent companies behave in an opportunistic manner by maximising personal interests at the expense of the other firm (Oxley \& Sampson, 2004; Park \& Ungson, 1997; Sengul, 2018).

As noted by Inkpen (2000), if the parent firms have a high degree of competitive overlap, then there would be a limited incentive for the firms to share their knowledge. As noted by Park and Ungson (1997), the parent company should shelve plans to collaborate with competitors.

H6: Competitive overlap and IJVs performance are negatively related in the new normal business landscape.

This study constitutes eight independent variables: cultural distance, administrative distance, geographic distance, economic distance, size asymmetry, competitive overlap, goal alignment, and resource complementarity, as shown in Figure 1.

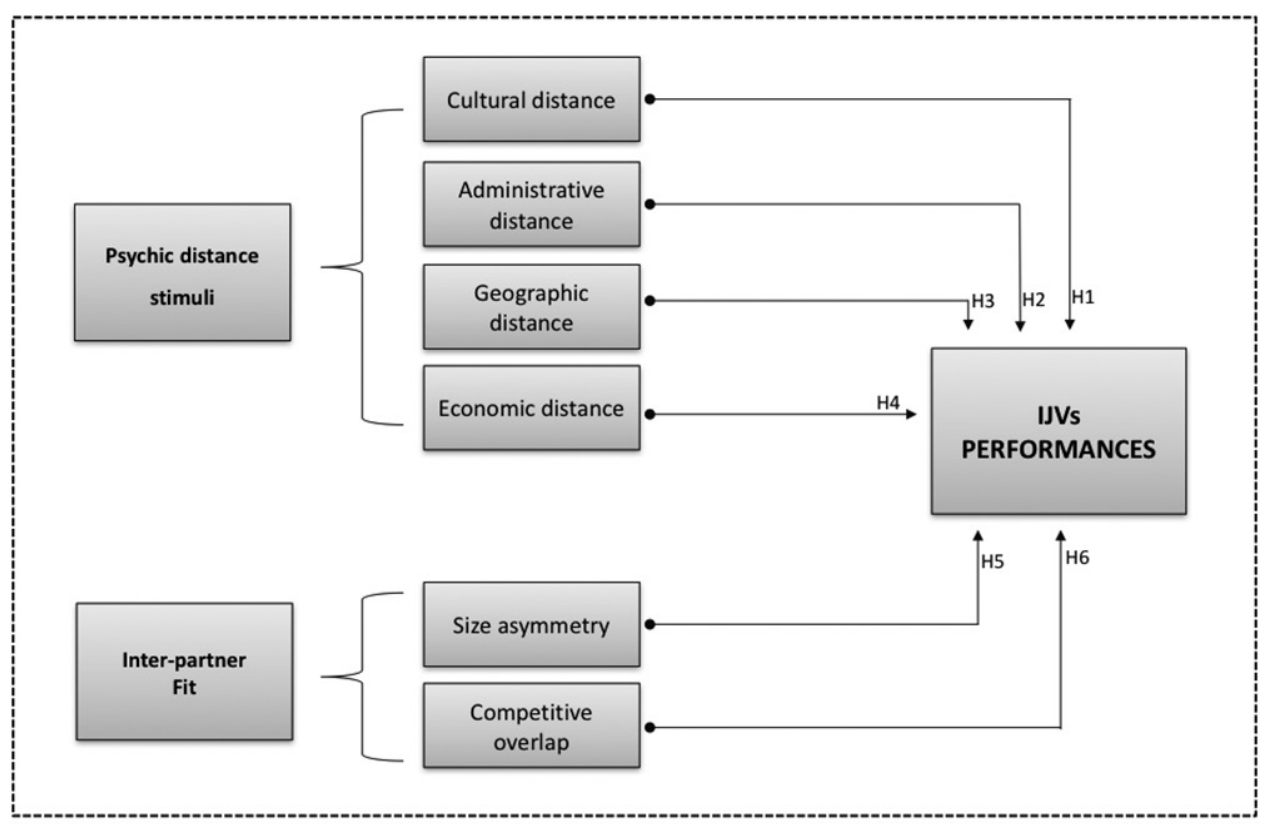

New normal business landscape

Figure 1. Conceptual framework 


\section{METHODS}

\section{Sample and Data Collection}

The analysis of this study is based on the collection of secondary data. IJVs headquartered in India are considered. The sampling criteria for selecting IJVs headquartered in India are as follows. IJVs formed with G7 economies - Canada, France, Japan, Italy, Germany, the United States, and the United Kingdom are considered; IJVs formed between 2008 and 2016; and IJVs involving only two partners. Data of 314 IJVs formed with G7 economies was obtained out of which 192 were dropped for non-availability of complete data for analysis, leaving 122 samples for analysis. The data consisted of IJVs from diverse industries including manufacturing, retail and wholesale, automotive, defence, investment, petroleum services, and telecommunication as shown in Table 1.

Table 1

Classification of types of industry

\begin{tabular}{lcc}
\hline Industry & Count & Percentage \\
\hline Automotive & 15 & 12.3 \\
Defence & 8 & 6.5 \\
Investment & 9 & 7.3 \\
Manufacturing & 43 & 35.2 \\
Petroleum services & 8 & 6.5 \\
Retail and wholesale & 18 & 14.8 \\
Telecommunication & 21 & 17.2 \\
\hline Total & 122 & 100.0 \\
\hline
\end{tabular}

\section{Variables and Measures}

\section{Dependent variable}

In this study, the performance of IJVs is considered as the dependent variable. To measure the performance, ROA has been used. Literature has widely accepted ROA as an indicator of a firm's performance (Arregle, Toyah, Hitt, \& Beamish, 2016; Dhir \& Dhir, 2018; Gomez-Mejia \& Palich, 1997; Hutzschenreuter et al., 2014; Lu \& Beamish, 2001, 2004). ROA is used to measure the efficiency with which output is produced by a firm. It is well-suited for analysing the performance of the firm's operations (Gomez-Mejia \& Palich, 1997). The information about ROA is obtained from "Ace Equity" database (http://www.aceanalyser.com/). 


\section{Independent variables}

This study constitutes eight independent variables: cultural distance, administrative distance, geographic distance, economic distance, size asymmetry, competitive overlap, goal alignment, and resource complementarity. In the extant literature, these variables have been extensively studied using primary data. However, for this study, secondary data is considered and different ways to measure each of these variables are identified. First, for culture distance, the method which is developed by Kogut and Singh (1988) is adopted. This index is widely used to calculate the compound measures of cultural distance between any two countries. This index is applied by many researchers (Sousa \& Bradley, 2006) for calculating the index Hofstede's cultural dimensions based on power distance, individualism, masculinity, uncertainty avoidance, and long-term orientation. We have used these five attributes to calculate the cultural index.

$$
C D j p=\sum_{i=1}^{5} \frac{\left[(I i j-I i p)^{2}\right]}{V j} / 5
$$

\section{Administrative distance}

For measuring administrative/governance distance, the indicators given by the World Bank are used (Beugelsdijk, Kostova, \& Roth, 2017; Kogut \& Singh, 1988; Sousa \& Bradley, 2006). The six worldwide governance indicators are rule of law, regulatory quality, control of corruption, political stability and absence of violence/terrorism, voice and accountability, and government effectiveness. These are the six indicators which provide a comprehensive view of the administrative differences between countries and are widely used in international business research (Kaufmann et al., 2009). To calculate the composite index, Kogut and Singh's index has been used.

\section{Geographic distance}

For the purpose of measuring the geographical distance between two countries, distance in kilometers between the centres of both the countries is measured (Håkanson \& Ambos, 2010; Rao, Pearce, \& Xin, 2005). 


\section{Economic distance}

This study measures the economic distance between countries on the basis of GDP per capita. The information of GDP per capita is obtained from the World Development Indicator database (https://datacatalog.worldbank.org/dataset/ world-development-indicators), which is a prominent database provided by the World Bank. This measure is widely accepted to gauge the economic differences between countries (Kraus, Ambos, Eggers, \& Cesinger, 2015).

\section{Size asymmetry}

The size of partners is measured by the number of employees working in the parent firms of the IJVs (Dow, 2006; Håkanson \& Ambos, 2010; Hutzschenreuter et al., 2014). The difference in the number of employees depicts the size asymmetry of the partners (Crutchley, Guo, \& Hansen, 1991). The information regarding the number of employees is extracted from the Securities Data Company (SDC) platinum.

\section{Competitive overlap}

Competitive overlap is measured through the standard industrial classification (SIC) code overlap and difference. SIC codes of the parent firms of IJVs are extracted from SDC platinum and annual reports (Nisar, Boateng, \& Wu, 2017).

\section{Control variables}

We controlled for factors other than the mentioned above that are expected to influence the performance of IJVs. First, we controlled the age of IJVs. Age of IJV is measured by the number of years since the IJVs had been established (Cuypers, Ertug, Reuer, \& Bensaou, 2017). Secondly, the type of industry is controlled for by analysis (Cuypers et al., 2017; Sim \& Ali, 2000).

\section{Data Analysis}

In this study to examine the hypothesised relationships, correlation and regression analysis is used. Multiple regression is used as it is helpful when there are several independent variables that are not strongly interrelated. It is a statistical technique that can be used to estimate the single dependent variable from the data of two or more independent variables. Our interest is to identify the impact of these variables on the measure of performance. Stata 14 statistics software package has been used to run multiple regression analysis and test the hypotheses. 


\section{FINDINGS}

Table 2 reports correlation for all variables along with its significance in the order hypothesised. For the purpose of checking multicollinearity, we have used the variance of inflation factor (VIF) test. The mean VIF score is 1.95 , far below the cutoff point of 10 .

Table 3 shows the result of multiple regression. It has found out that the coefficient of cultural distance is opposite to what is hypothesised but significant. The coefficient of administrative distance negatively impacts the performance of IJVs and is significant with $(-5.49 ; p<0.05)$. Hence, support is given for the hypothesis that administrative distance has a negative effect on the performance of IJVs (H2). $\mathrm{H} 4$ states that the economic distance will negatively impact the performance of IJVs with statistically significance $(\beta=-2.96 ; p<0.01)$. H5 posits that the more the competitive overlap between the parents of IJVs, the worse will be the performance. The result shows that the competitive overlap is significant with a negative coefficient $(\beta=-0.002 ; p<0.05)$. This shows that competitive overlap inversely affects the performance of IJVs. Contrary to expectations, geographic distance is not significantly related to performance $(p>0.05)$, thus indicates that there is a lack of support for the hypothesis. Size asymmetry is hypothesised to negatively impact the performance of IJVs, however, on the contrary, it is insignificant.

\section{DISCUSSIONS AND CONTRIBUTIONS}

Recently, scholarly research on IJVs has significantly articulated the need for extensive research in regard to factors affecting the performance of IJVs in the context of the new normal business landscape. This research has empirically examined the effect psychic distance stimuli and inter-partner fit have on the performance of IJVs headquartered in emerging economies such as India. The findings in this empirical research support the fundamental argument that when evaluating the IJVs' performance in the new normal landscape, psychic distance stimuli and inter-partner fit need to be considered. Extant literature has argued that psychic distance stimuli lead to frictions in international business (Hagedoorn, 1993). Therefore, we have argued that it will impact the performance of IJVs negatively. Literature has taken into consideration the effect of one specific distance; however, this study takes into consideration multidimensional distance stimuli - cultural, administrative, geographic, and economic. It gives a comprehensive view of psychic distance stimuli in regard to the performance of 


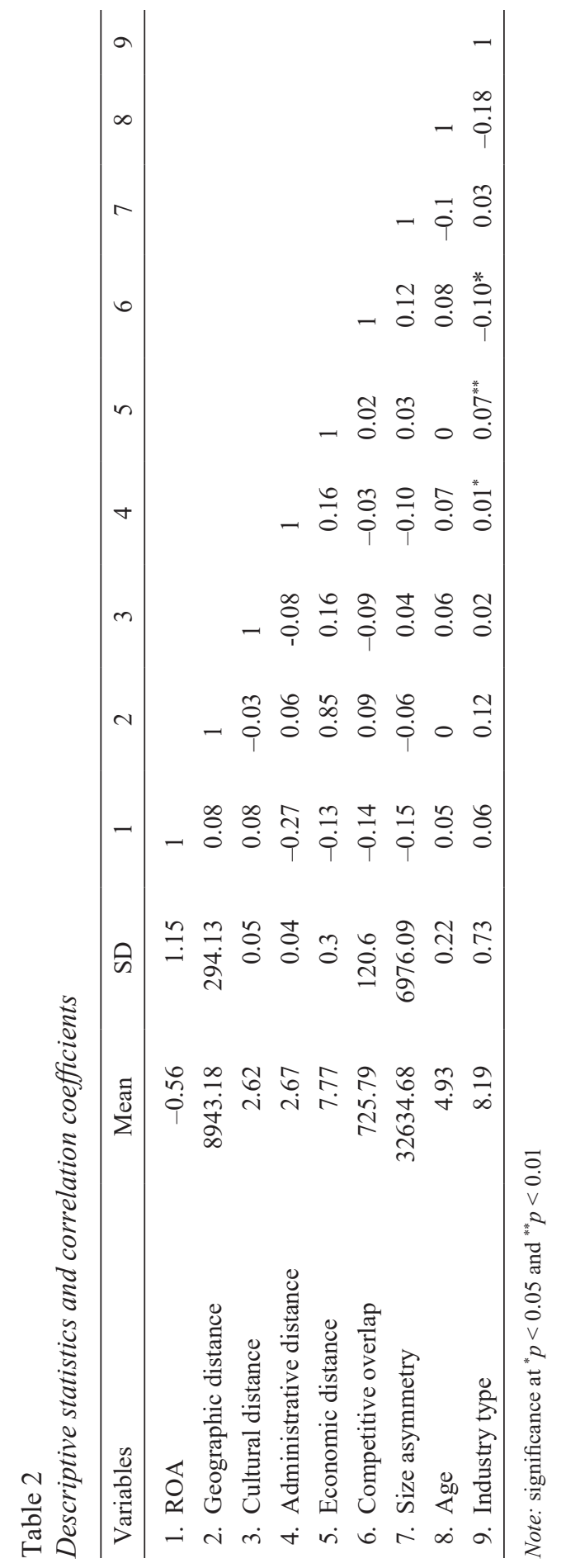


Table 3

Multiple regression analysis results

\begin{tabular}{llc}
\hline Variables & Beta & $t$ \\
\hline Geographic distance & 0 & 4.58 \\
Cultural distance & 4.04 & 2.21 \\
Administrative distance & -5.49 & $-2.41^{*}$ \\
Economic distance & -2.96 & $-2.41^{*}$ \\
Competitive overlap & -0.01 & $-2.41^{*}$ \\
Size asymmetry & 0 & -1.05 \\
Age & 0.31 & 0.72 \\
Industry type & 0.01 & 0.11 \\
R square & 0.28 & \\
Adjusted R & 0.23 & \\
F & $5.40^{*}$ & \\
\hline
\end{tabular}

Note: significance at ${ }^{*} p<0.05$

IJVs. As such, the research provides a review of the effect of different psychic distance stimuli on IJVs' performance and therefore, contributes to the current "new normal" debate in a number of ways.

Although the cultural distance is positioned as the major factor affecting the performance of IJVs, the hypothesis is the opposite of the calculated coefficient. In the extant literature, there exist mixed results; some results have reported the negative sign coefficient (Shenkar, Luo, \& Yeheskel, 2008) while the other group has reported a positive relationship (Brouthers, 2002). The results have shown that cultural distance can sometimes favourably affect the performance of IJVs. This implies that firms should not shy away from operating in unfamiliar cultures. Nevertheless, it has been shown that geographic distance has no significant impact on the IJVs' performance. The geographic distance may not hamper performance because of the advancement of communication and transportation facilities.

Interestingly, the results show that administrative or governance distance significantly affects the performance of IJVs. The more complex the governance of a country is, the more difficult it is to operate in that country. However, the study was unable to point at significant effect resulting from size asymmetry.

Competitive overlap has a negative coefficient; it is significant with a value of $p<0.05$. IJVs portray a unique setting where companies have to deal with external challenges as well as deal with their partners within the IJVs in ensuring the other firm does not behave in an opportunistic manner. Therefore, the psychic distance 
and inter-partner fit have been and remain important predictors of the performance of IJVs. The examination of these two main factors will provide a new perspective on IJVs' performance to an academician. The present study contributes to the distance literature by showing apart from the cultural distance, other distances such as administrative and economic distances affect the IJVs' performance. Additionally, the effects of different distances are compared and they help to know, which distance is comparatively more significant. CAGE framework, developed by Ghemawat (2010), provides a valid and comprehensive way of understanding the different perspectives of psychic distance stimuli. Despite the rigour and comprehensiveness of this framework, to our knowledge, not much significant work has been done using the same framework. Lastly, to our knowledge, this study is the first work, which has evaluated the performance of IJVs headquartered in India with G7 economies.

\section{Implications}

The findings of this study will help managers in the partner selection procedure. Psychic distance stimuli with larger effects have been discussed and this will help managers to understand, which distances one has to pay more attention to. This will help them to mitigate the hindrances in doing international business. Additionally, this study will be of use to policymakers by helping them to understand the best avenues for IJVs formation. For example, "Make in India" campaign of the Government of India has motivated firms to enter into new business domains. Similarly, the new goods and services tax (GST) introduction has made the administrative environment more conducive; this has reduced the governance distance and attracted firms abroad to operate in India.

\section{CONCLUSION}

This work has argued and demonstrated that psychic distance stimuli in the new normal business context affect the performance of IJVs significantly. A hallmark of psychic distance stimuli in emerging economies is the simultaneous coexistence of political power distance and market forces. The contingency effects of competitive overlap further demonstrate their impact on the performance of IJVs. Overall, this study makes and substantiates the case that economic and administrative distances matter in the performance of IJVs. 


\section{Limitations and Future Research Directions}

Despite the innumerable strengths of this research, there is a presence of limitations that the future research has to address. One of the limitations is that this study is based on secondary data pertaining to IJVs headquartered in India. This makes it hard to generalise these results to other upcoming economies. Further, only psychic distance stimuli and inter-partner fit have been identified to influence performance in the context of new normal business landscape. One cannot dispute that other unforeseen factors can affect the performance of IJVs. Second is the issue of generalisability of the findings. IJVs formed with the host country, India, and G7 countries are taken into consideration. Therefore, to be able to generalise the findings of this study, other emerging economies must be researched.

\section{REFERENCES}

Ahsan, M., \& Fernhaber, S.A. (2019). Multinational enterprises: Leveraging a corporate international entrepreneurship lens for new insights into subsidiary initiatives. Journal of International Management, 25(1), 51-65. https://doi.org/10.1016/j. intman.2018.07.002

Alcantara, L.L., \& Hoshino, Y. (2012). Modes of acquiring host-country experience and performance of international joint ventures in Japan. Asian Business \& Management, 11(2), 123-148. https://doi.org/10.1057/abm.2011.30

Arregle, J., Toyah, L., Hitt, M.A., \& Beamish, P.W. (2016). How does regional institutional complexity affect MNE internationalization? Journal of International Business Studies, 47(6), 1-26. https://doi.org/10.1057/jibs.2016.20

Atolia, M., Gibson, J., \& Marquis, M. (2018). Asymmetry and the amplitude of business cycle fluctuations: A quantitative investigation of the role of financial frictions. Macroeconomic Dynamics, 22(2), 279-306. https://doi.org/10.1017/ s1365100516000171

Awadzi, W.K. (1987). Determinants of joint venture performance: A study of international joint ventures in the United States (Japan, Europe). $\mathrm{PhD}$ dissertation, Louisiana State University and Agricultural and Mechanical College.

Barmeyer, C., \& Davoine, E. (2019). Facilitating intercultural negotiated practices in joint ventures: The case of a French-German railway organization. International Business Review, 28(1), 1-11. https://doi.org/10.1016/j.ibusrev.2018.06.001

Barney, J. (1991). Firm resources and sustained competitive advantage. Journal of Management, 17(1), 99-120. https://doi.org/10.1177/014920639101700108

Beamish, P.W. (1988). Multinational joint ventures in developing countries. London: Routledge.

Beck, U. (2018). What is globalization? Cambridge, UK: Polity Press.

Beckerman, W. (1956). Distance and the pattern of intra-European trade. The Review of Economics and Statistics, 38(1), 31-40. 
Beugelsdijk, S., Kostova, T., \& Roth, K. (2017). An overview of Hofstede-inspired country-level culture research in international business since 2006. Journal of International Business Studies, 48(1), 30-47. https://doi.org/10.1057/s41267016-0038-8

Brouthers, K.D. (2002). Institutional, cultural and transaction cost influences on entry mode choice and performance. Journal of International Business Studies, 33(2), 203-221. https://doi.org/10.1057/palgrave.jibs.8491013

Cairncross, F. (1997). The death of distance: How the communications revolution will change our lives. International Marketing Review, 15(4), 309-311. https://doi. org/10.1108/imr.1998.15.4.309.1

Chatterjee, S., Lubatkin, M.H., Schweiger, D.M., \& Weber, Y. (1992). Cultural differences and shareholder value in related mergers: Linking equity and human capital. Strategic Management Journal, 13(5), 319-334. https://doi.org/10.1002/ smj.4250130502

Child, J., Chung, L., \& Davies, H. (2003). The performance of cross-border units in China: A test of natural selection, strategic choice and contingency theories. Journal of International Business Studies, 34(3), 242-254. https://doi.org/10.1057/palgrave. jibs. 8400033

Choi, C., \& Beamish, P.W. (2004). Split joint venture. Journal of International Business Studies, 35(3), 201-215.

Clark, X., Dollar, D., \& Micco, A. (2004). Port efficiency, maritime transport costs, and bilateral trade. Journal of Development Economics, 75(2), 417-450. https://doi. org/10.1016/j.jdeveco.2004.06.005

Crutchley, C.E., Guo, E., \& Hansen, R.S. (1991). Stockholder benefits from JapaneseUS joint ventures. Financial Management, 20(4), 22-30. https://doi. org/10.2307/3665709

Culpan, R. (2008). The role of strategic alliances in gaining sustainable competitive advantage for firms. Management Review, 19(1/2), 94-105. https://doi. org/10.5771/0935-9915-2008-1-2-94

Cuypers, I.R.P., Ertug, G., Reuer, J.J., \& Bensaou, B. (2017). Board representation in international joint ventures. Strategic Management Journal, 38(4), 920-938. https://doi.org/10.1002/smj.2529

Damanpour, F., Devece, C., Chen, C.C., \& Pothukuchi, V. (2012). Organizational culture and partner interaction in the management of international joint ventures in India. Asia Pacific Journal of Management, 29(2), 453-478. https://doi.org/10.1007/ s10490-010-9204-x

Das, T.K., \& Teng, B. (2003). Partner analysis and alliance performance. Scandinavian Journal of Management, 19(3), 279-308. https://doi.org/10.1016/s09565221(03)00003-4

Davis, I. (2009). The new normal. The McKinsey Quarterly. Retrieved from https:// washburn.edu/faculty/rweigand/McKinsey/McKinsey-The-New-Normal.pdf

Demirbag, M., \& Mirza, H. (2000). Factors affecting international joint venture success: An empirical analysis of foreign-local partner relationships and performance in joint ventures in Turkey. International Business Review, 9(1), 1-35. https://doi. org/10.1016/s0969-5931(99)00027-x 
Dhir, S. (2017). Flexibility in modification and termination of cross-border joint ventures. Global Journal of Flexible Systems Management, 18(2), 139-151. https://doi. org/10.1007/s40171-017-0153-9

Dhir, S., \& Dhir, S. (2018). Role of ambidexterity and learning capability in firm performance: A study of e-commerce industry in India. VINE Journal of Information and Knowledge Management Systems, 48(4), 517-536. https://doi. org/10.1108/vjikms-10-2017-0073

Dhir, S., \& Mital, A. (2013). Value creation on bilateral cross-border joint ventures: Evidence from India. Strategic Change, 22(5-6), 307-326. https://doi.org/10.1002/jsc. 1942

Dhir, S., Ongsakul, V., \& Batra, I. (2018). Comprehending ambidexterity in the emerging market context: The moderating role of learning capability and environmental dynamism on e-commerce firms' performance. Journal for Global Business Advancement, 11(4), 395-417. https://doi.org/10.1504/jgba.2018.10018210

Dow, D. (2006). Developing a multidimensional instrument to measure psychic distance stimuli. Journal of International Business Studies, 37(5), 578-602. https://doi. org/10.1057/palgrave.jibs.8400221

El-Erian, M. (2010). Navigating the new normal economy in industrial countries. Washington, DC: Per Jacobsson Foundation.

Evans, J., Treadgold, A., \& Mavondo, F.T. (2000). Explaining export development through psychic distance. International Marketing Review, 17(2), 164-169. https://doi. org/10.1108/02651330010322688

Falkenberg, J., \& Ashurst, C. (2010). Guest editorial: The new normal - Implications for change. Journal of Change Management, 10(2), 131-133. https://doi. org/10.1080/14697011003795560

Fatehi, K., \& Choi, J. (2019). The management of international business. In K. Fatehi, \& J. Choi, International business management: Succeeding in a culturally diverse world (pp. 3-35). Cham, Switzerland: Springer. https://doi.org/10.1007/978-3319-96622-9

Geringer, M., \& Herbert, L. (1989). Control and performance of international joint ventures. Journal of International Business Studies, 20(2), 235-254.

Geringer, M., \& Herbert, L. (1991). Measuring performance of international joint ventures. Journal of International Business Studies, 22(2), 249-263.

Ghemawat, P. (2001). Distance still matters. Harvard Business Review, 79(8), 137-147.

Ghemawat, P. (2010). Finding your strategy in the new landscape. Harvard Business Review, 88(2), 54-60.

Glaister, K.W., \& Buckley, P.J. (1998). Management-performance relationships in UK joint ventures. International Business Review, 7(3), 235-257. https://doi.org/10.1016/ s0969-5931(98)00008-0

Gomez-Mejia, L.R., \& Palich, L.E. (1997). Cultural diversity and the performance of multinational firms. Journal of International Business Studies, 28(2), 309-335. https://doi.org/10.1057/palgrave.jibs.8490103

Hagedoorn, J. (1993). Understanding the rationale of strategic technology partnering: Interorganizational modes of cooperation and sectoral differences. Strategic Management Journal, 14(14), 371-385. https://doi.org/10.1002/smj.4250140505 
Håkanson, L., \& Ambos, B. (2010). The antecedents of psychic distance. Journal of International Management, 3(16), 195-210. https://doi.org/10.1016/j. intman.2010.06.001

Hamel, G., Doz, Y.L., Prahalad, C.K., Kandampully, J., Lu, D., \& Sawhney, M. (1989). Collaborate with your competitors and win. Harvard Business Review, 67(1), 133-139.

Hamid, H.A., Everett, A.M., \& O’Kane, C. (2018). Ethnic migrant entrepreneurs' opportunity exploitation and cultural distance: A classification through a matrix of opportunities. Asian Academy of Management Journal, 23(1), 151-169. https://doi.org/10.21315/aamj2018.23.1.7

Hamilton, R., Dana, L.P., \& Benfell, C. (2008). Changing cultures: An international study of migrant entrepreneurs. Journal of Enterprising Culture, 16(1), 89-105. https://doi.org/10.1142/s0218495808000053

Harrigan, K.R. (1988). Joint ventures and competitive strategy. Strategic Management Journal, 9(2), 141-158.

Head, K., Li, Y.A., \& Minondo, A. (2018). Geography, ties, and knowledgeflows: Evidence from citations in mathematics (CEP Discussion Paper No. 1554). London: Centre for Economic Performance, London School of Economics and Political Science. https://doi.org/10.2139/ssrn.3163679

Hiatt, S.R, \& Wesley, D. (2014). Clear and present danger: Planning and new venture survival amid political and civil violence. Strategic Management Journal, 35(5), 773-785. https://doi.org/10.1002/smj.2113

Hill, R.C., \& Hellriegel, D. (1994). Critical contingencies in joint venture management: Some lessons from managers. Organisation Science, 5(4), 594-607. https://doi. org/10.1287/orsc.5.4.594

Hitt, M.A., Li, D., \& Xu, K. (2016). International strategy: From local to global and beyond. Journal of World Business, 51(1), 58-73.

Hofstede, G. (1980). Motivation, leadership and organisation: Do American theories apply abroad? Organizational Dynamics, 9(1), 42-63. https://doi.org/10.1016/00902616(80)90013-3

Hutzschenreuter, T., Kleindienst, I., \& Lange, S. (2014). Added psychic distance stimuli and MNE performance: Performance effects of added cultural, governance, geographic, and economic distance in MNEs' international expansion. Journal of International Management, 20(1), 38-54. https://doi.org/10.1016/j. intman.2013.02.003

Inkpen, A.C. (2000). Learning through joint ventures: A framework of knowledge acquisition. Journal of Management Studies, 37(7), 1019-1043.

Jemison, D.B., \& Sitkin, S.B. (1986). Corporate acquisitions: A process perspective. The Academy of Management Review, 11(1), 145-163. https://doi.org/10.5465/ amr.1986.4282648

Karunaratna, A., \& Dow, D. (2006). Developing a multidimensional instrument to measure psychic distance stimuli. Journal of International Business Studies, 37(5), 578602. https://doi.org/10.1057/palgrave.jibs.8400221 
Kaufmann, D., Kraay, A., \& Mastruzzi, M. (2009). Governance matters VIII: Aggregate and individual governance indicators 1996-2008 (Policy Research Working Paper No. WPS 4978). Washington, DC: World Bank. https://doi.org/10.1596/18139450-4978

Kostova, T., \& Marano, V. (2019). Institutional theory perspectives on emerging markets. In R. Grosse, \& K.E. Meyer (Eds.), Oxford handbook of management in emerging markets (p. 99-126). Oxford, UK: Oxford University Press. https://doi. org/10.1093/oxfordhb/9780190683948.013.5

Killing, J.P. (1983). Strategies for joint venture success. New York: Praeger.

Kogut, B. (1988). Joint ventures: Theoretical and empirical perspectives. Strategic Management Journal, 9(4), 319-332. https://doi.org/10.1002/smj.4250090403

Kogut, B., \& Singh, H. (1988). The effect of national culture on the choice of entry mode. Journal of International Business Studies, 19(3), 411-432. https://doi. org/10.1057/palgrave.jibs.8490394

Kraus, S., Ambos, T.C., Eggers, F., \& Cesinger, B. (2015). Distance and perceptions of risk in internationalization decisions. Journal of Business Research, 68(7), 1-5. https://doi.org/10.1016/j.jbusres.2015.01.041

Lane, P.R., \& Milesi-Ferretti, G.M. (2018). The external wealth of nations revisited: International financial integration in the aftermath of the global financial crisis. IMF Economic Review, 66(1), 189-222. https://doi.org/10.1057/s41308-0170048-y

Lasserre, P. (1999). Joint-venture satisfaction in Asia Pacific. Asia Pacific Journal of Management, 16(1), 1-28.

Lee, C., \& Beamish, P. (1995). The characteristics and performance of Korean joint ventures in LDCs. Journal of International Business Studies, 26(3), 637-654. https://doi.org/10.1057/palgrave.jibs.8490190

Li, J., \& Hambrick, D. (2005). Factional groups: A new vantage on demographic faultiness, conflict, and disintegration in work teams. The Academy of Management Journal, 48(5), 794-813. https://doi.org/10.5465/amj.2005.18803923

Li, W., \& Wang, L. (2019). Strategic choices of exploration and exploitation alliances under market uncertainty. Management Decision. https://doi.org/10.1108/MD-01-20170073

Li, X. (2003). Control in Japanese-Chinese joint ventures: Antecedent factors and effect on performance from the Japanese viewpoint. Asian Business \& Management, 2(3), 371-391. https://doi.org/10.1057/palgrave.abm.9200061

Lin, Y.-H., Chen, C.-J., \& Lin, B.-W. (2014). The roles of political and business ties in new ventures: Evidence from China. Asian Business \& Management, 13(5), 411-440. https://doi.org/10.1057/abm.2014.14

Lowen, A., \& Pope, J. (2008). Survival analysis of international joint venture relationships. Journal of Business and Economics Studies, 14(1), 62-80.

Lu, J.W., \& Beamish, P.W. (2001). The internationalization and performance of SMEs. Strategic Management Journal, 22(6-7), 565-586. https://doi.org/10.1002/ smj.184.abs 
Lu, J.W., \& Beamish, P.W. (2004). International diversification and firm performance: The s-curve hypothesis. Academy of Management Journal, 47(4), 598-609. https:// doi.org/10.2307/20159604

Luo, Y. (2005). How important are shared perceptions of procedural justice in cooperative alliances? Academy of Management Journal, 48(4), 695-709. https://doi. org/10.5465/amj.2005.17843946

Marquis, C., \& Raynard, M. (2015). Institutional strategies in emerging markets. Academy of Management Annals, 9(1), 291-335. https://doi.org/10.5465/19416520.2015. 1014661

Marquis, C., \& Zhang, J. (2011). Regulatory uncertainty and corporate response: How China's environmental enforcement is catching up to regulation and how business can keep up. California Management Review, 54(1), 39-63.

Melville, P., \& Reese, S. (2009). Restructuring for the "new" normal. Financial Executive, 25(6), 26-30.

Meyer, K.E., Mudambi, R., \& Narula, R. (2011). Multinational enterprises and local contexts: The opportunities and challenges of multiple embeddedness. Journal of Management Studies, 48(2), 235-252. https://doi.org/10.1111/j.14676486.2010.00968.X

Murrell, P., \& Wang, Y. (1993). When privatization should be delayed: The effect of communist legacies on organizational and institutional reforms. Journal of Comparative Economics, 17(2), 385-406. https://doi.org/10.1006/jcec.1993.1031

Nachum, L., \& Zaheer, S. (2005). The persistence of distance? The impact of technology on MNE motivations for foreign investment. Strategic Management Journal, 26(8), 747-767. https://doi.org/10.1002/smj.472

Nakos, G., \& Brouthers, K.D. (2008). International alliance commitment and performance of small and medium-size enterprises: The mediating role of process control. Journal of International Management, 14(2), 124-137. https://doi.org/10.1016/j. intman.2007.11.001

Nasurdin, A.M., Jantan, M., \& Fadzil, N.F.A. (2004). Country of origin effect on organizational innovation in Malaysia: The mediating role of structure. Asian Academy of Management Journal, 9(2), 63-85.

Nisar, S., Boateng, A., \& Wu, J. (2017). The entry mode strategy and performance of SMEs: Evidence from Norway. Research in International Business and Finance, 45(October), 323-333. https://doi.org/10.1016/j.ribaf.2017.07.164

Ömür, G.A., Tunç, A.Ö., \& Düren, A.Z. (2012). Patterns of mergers and acquisitions in Turkey in the era of "new normal". Procedia - Social and Behavioral Sciences, 58(October), 1611-1617. https://doi.org/10.1016/j.sbspro.2012.09.1148

Osland, G.E., \& Cavusgil, S.T. (1996). Performance issues in US-China joint ventures. California Management Review, 38(2), 106-130. https://doi. org/10.2307/41165835

Oxley, J.E., \& Sampson, R.C. (2004). The scope and governance of international R\&D alliances. Strategic Management Journal, 25(8-9), 723-749.

Park, S., \& Ungson, G. (1997). The effect of national culture, organizational complementarity, and economic motivation on joint venture dissolution. The Academy of Management Journal, 40(2), 279-307. https://doi.org/10.2307/256884 
Parkhe, A. (1991). Interfirm diversity, organizational learning, and longevity in global strategic alliances. Journal of International Business Studies, 22(4), 579-601. https://doi.org/10.1057/palgrave.jibs.8490315

Rao, A.N., Pearce, J.L., \& Xin, K. (2005). Governments, reciprocal exchange and trust among business associates. Journal of International Business Studies, 36(1), 104 118. https://doi.org/10.1057/palgrave.jibs.8400116

Ren, H., Gray, B., \& Kim, K. (2009). Performance of international joint ventures: What factors really make a difference and how? Journal of Management, 35(3), 805-832. https://doi.org/10.1177/0149206308331165

Scott, W.R. (1995). Institutions and organizations: Ideas, interests, and identities. Los Angeles, CA: Sage Publications.

Shenkar, O., Luo, Y., \& Yeheskel, O. (2008). From "distance" to "friction": Substituting metaphors and redirecting intercultural research. The Academy of Management Review, 33(4), 905-923. https://doi.org/10.5465/amr.2008.34421999

Sengul, M. (2018). Organization design and competitive strategy: An application to the case of divisionalization. In B. Silverman (Ed.), Organization design (Advances in strategic management, Volume 40) (pp. 207-228) London: Emerald Publishing Limited. https://doi.org/10.1108/s0742-332220180000040007

Sim, A B., \& Ali, M. Y. (2000). Determinants of stability in international joint ventures: Evidence from a developing country context. Asia Pacific Journal of Management, 17(3), 373-397.

Sousa, C.M.P., \& Bradley, F. (2006). Cultural distance and psychic distance: Two peas in a pod? Journal of International Marketing, 14(1), 49-70. https://doi.org/10.1509/ jimk.14.1.49

Srivastava, R.K., \& Green, R.T. (1986). Determinants of bilateral trade flows. The Journal of Business, 59(4), 623-640.

Tan, C.L., \& Mohd Nasurdin, A. (2010). The influence of knowledge management effectiveness on administrative innovation among Malaysian manufacturing firms. Asian Academy of Management Journal, 15(1), 63-77.

Wang, Y. (2006). Inside contractual joint ventures in China: Ownership advantage, resource contribution and management control. Asian Business \& Management, 5(3), 379-398. https://doi.org/10.1057/palgrave.abm.9200192

Weber, Y., Shenkar, O., \& Raveh, A. (1996). National and corporate cultural fit in mergers/ acquisitions: An exploratory study. Management Science, 42(8), 1215-1227. https://doi.org/10.1287/mnsc.42.8.1215

Yan, A., \& Duan, J. (2003). Inter-partner fit and its performance implications: A four-case study of US-China joint ventures. Asia Pacific Journal of Management, 20(4), 541-564.

Zhao, H., Ma, J., \& Yang, J. (2017). 30 years of research on entry mode and performance relationship: A meta-analytical review. Management International Review, 57(5), 653-682. https://doi.org/10.1007/s11575-017-0314-2 